\title{
FOOD EXPERIENCE DESIGN TO PREVENT UNINTENDED CONSEQUENCES AND IMPROVE WELLBEING
}

Michela Addis, Università degli Studi Roma Tre, Rome, Italy

Wided Batat, EM Normandie Business School, Metis Lab \& University of Lyon 2, Paris, France

Sinem S. Atakan, Siena College, US

Caroline Graham Austin, Jake Jabs College of Business \& Entrepreneurship, Montana State University, US

Danae Manika, Brunel Business School, Brunel University London, UK

Paula C. Peter, Marketing Department, San Diego State University, US

Lane Peterson, Marketing Department, Georgia State University, US

The authors thank Beth Vallen, along with the co-editors of the special issue and the four anonymous reviewers, whose comments and suggestions helped improve the contribution of this paper. Special thanks go to the expert managers who work in the food industry for their particular comments on previous drafts: Azzurra Spina, shopper experience director for Europe at The Coca-Cola Company, and Emanuele Taccini, regional marketing manager, Kinder brands portfolio, at Ferrero (Africa, Levant, and Israel).

Keywords: ethical principles, food experience, food design, food well-being, ethical food experience design, unintended consequences, services 


\title{
Food Experience Design to Prevent Unintended Consequences and Improve Wellbeing
}

\begin{abstract}
This article introduces a novel and comprehensive conceptual framework for designing innovative food experiences that enhance food well-being. We call this framework the novel food experience design. It supports managers in cocreating customer-centric food experiences to limit unintended detrimental consequences and enhance individual and societal food well-being. The novel food experience design (1) employs a systemic (vs. endemic) approach to the innovation process and (2) promotes prioritizing ethical decision-making alongside economic decisionmaking. Building on insights derived from ecosystem theory and the ethical principles literature, we develop four fundamental propositions to innovate food experiences: do no harm, do good, ensure autonomy, and ensure fairness. Our framework promotes higher levels of individual and societal food well-being than restricted food design innovations, preventing unintended consequences. Finally, we illuminate the implications for service research and practice.
\end{abstract}


Food design is the processes of innovation related to food (Zampollo 2016). Though developed with the best intentions in mind, food design often suffers from unintended consequences. For example, the United Kingdom's "Eat Out to Help Out" scheme, a governmental response to the COVID-19 pandemic, subsidized 50\% of the cost of food and nonalcoholic drinks at participating restaurants to encourage people to eat out (Monday-Wednesday) as a way to protect 1.8 million jobs. The scheme stimulated demand in more than 78,000 participating outlets (HM Revenue \& Customs 2020), and the frequency of eating out was nearly twice that during the same period in 2019 (BBC 2020). Nevertheless, the scheme unintentionally led to the loss of human life (i.e., it contributed to the second wave of the novel coronavirus; Fetzer 2020), benefited only middleand higher-income households, led to a higher level of hostility toward staff due to long queues that threatened service standards, and was criticized for its potential connection with obesity. This is only one example of when food design innovation, developed to ensure economic stability, results in multiple unintended consequences. Such consequences are likely to occur when a robust conceptual framework is lacking (MacKenzie 2003). Specifically, many innovation practices are "too slow, expensive and inflexible" (Lundahl 2012, p. 7). Thus, we propose a revision of the food innovation process to address unintended consequences of food design and offer actionable advice for managers. According to Patrício and Fisk (2013, p. 191), “[t]o create new services, it is important to understand what is designed, but also how services are designed." First, regarding the what is designed issue, "a more positive, holistic understanding of the role of food in a person's overall well-being" (Block et al. 2011, p. 5) rather than just physical health (Bublitz et al. 2011; Bublitz et al. 2019; Scott and Vallen 2019) is necessary. This view of food well-being encompasses the experiential and hedonic dimensions of food (Batat 2019). What should be designed is the food experience rather than the food product itself, as previous research highlights. Indeed, some companies, especially those in international contexts, have begun 
designing the full experience rather than core products. Food (full) experiences that are sensory, subjective, and highly symbolic (Addis and Holbrook 2019) begin with interactions among particular stimuli that vary in intensity, levels of control, and levels of aggregation (Becker and Jaakkola 2020) and take place during the customer journey, generating multidimensional customer responses (Lemon and Verhoef 2016). When managers adopt a restricted view of what they design — addressing the design of food products rather than consumers' experiences and interactions with the food - they then must focus on pure marketing to approach their targets. However, in these situations, they can unintentionally, but easily, generate negative, even dangerous consequences. For example, hyperpalatable foods are designed with increased levels of sugar, fat, salt, and flavor, which are inevitability tasty but have addictive effects that lead to various negative outcomes for individual consumers and overall public health.

Second, the issue of how to design has long adopted a restricted approach, related to both innovation (endemic vs. systemic) and decision-making processes (economic vs. ethical), generating unintended consequences, such as in the "Eat Out to Help Out" example. Managers who base food design decisions only on economic factors might ignore other dimensions of food experiences, leading to poor market performance of the final experiences. In addition, managers with restricted views of innovation might identify only a limited set of stakeholder concerns during the design process. For example, meal kit delivery services focus on innovating a homecooking system that reduces food waste. While this goal is admirable, these companies have been criticized for creating considerable amounts of other waste through their excessive use of plastics, individual packaging of ingredients, and the use of nonrecyclable ice packs (Lewis 2021).

We propose a novel conceptual framework of practical value to address these weaknesses of food design and help prevent unintended consequences. Our frame of reference adopts an ecosystemic approach to innovation processes (Chandler et al. 2019) and an ethical principles 
approach to food design (Mepham 1996a, 1996b; Ross 1930) to maximize food well-being. The proposed framework draws from innovation, design, and service literature to specifically build on the modern view of innovation based on customer valuation (Skålén et al. 2015; Yu and Sangiorgi 2018), the perceived value in design and innovation (Sudbury-Riley et al. 2020), consumers' role in increasing the effectiveness of new products (Friend and Malshe 2016), and the need to address the undesirable outcomes of service experience innovation (Patrício, Gustafsson, and Fisk 2018).

We propose that the four ethical principles of nonmaleficence, beneficence, autonomy, and justice (fairness) (Beauchamp and Childress 2001) can help guide firms and policy makers in developing a better experiential food design (Mepham 1996a, 1996b), resulting in enhanced food well-being and increased actor engagement. We aim to advance service experience innovation with a decision-making framework that assists in solving the conflicts that affect process innovation in ecosystems, such as tensions or divergences (Chandler et al. 2019), helping reduce the probability of unintended consequences. After reviewing food design literature and its unintended consequences, we present the systemic approach to innovation processes and the four ethical principles of food design to define the core concept of our framework and develop four related fundamental propositions (FPs). Furthermore, we illustrate the impact on food well-being as an outcome and elaborate on the implications for service research and practice.

\section{FOOD DESIGN LITERATURE AND UNINTENDED CONSEQUENCES}

Food design includes gathering data on user needs, generating ideas, and testing those ideas (Liedtka 2015). Despite its history of incorporating biology, anthropology, psychoanalysis, sociology, nutrition, marketing, consumer behavior, and service research (Zampollo 2016), food design has often given rise to severe unintended consequences that firms should be aware of, try to minimize, and, if possible, eliminate. 
Two widely used but restricted approaches have hindered the effectiveness of food design in promoting food well-being. The first is the endemic approach to innovation processes, which typically favors the interest of a single actor (e.g., a company’s owner) over other stakeholders (e.g., customers, suppliers, policy makers). Sociology, which deems inadequate knowledge, errors, and short-term interests dangerous elements of purposive action, has widely recognized this source of unintended consequences (Merton 1936). In particular, risk sociology calls for an open approach including multiple actors as the only strategy capable of addressing the anxieties and insecurities of the modern age (Beck 1997).

The endemic approach considers only a restricted range of resources in the innovation process (Helkkula, Kowalkowski, and Tronvoll 2018). A single actor's perspective (e.g., a single policy maker, a firm, an employee) dictates the activity even when considering others' resources (typically those of consumers). The decisions throughout the innovation process are traditionally made with this single actor in mind, but in complex contexts, any process innovation based only on a singular view is, by definition, inadequate. When an endemic approach is adopted, the risk of leaving out relevant interests is high. For example, in the children food segment, pleasing children (the users) might lead to poor food experiences that generate not only parents' (the purchasers') dissatisfaction but also relevant costs for doctors, schools, media (the influencers), and the society charged with nurturing those children. Another common example is the use of "fat taxes" attached to food items that contribute to obesity, which generates unintended consequences such as low-income groups paying a higher percentage of their income for this regressive tax than higher-income groups and increasing administrative costs (Pettinger 2019). These consequences also fail to take into account that the factors that contribute to obesity go far beyond food. 
The second restricted approach is economic decision-making, which profoundly shapes food design. The economic approach is grounded in the myth of the homo economicus, a supposedly rational actor (Levitt and List 2008) who only "engages with others in a transactional manner to fulfill his or her financial interests. He/she is amoral, values short-term gratification, and often acts opportunistically to further personal gain" (Pirson and Lawrence 2010, p. 553). When sales are the critical challenge for firms aiming to develop new solutions, the simplicity of the whole process is a key goal. This understanding of human motivations and behavior is unrealistic (Thaler 2000) and, as a consequence, has the potential to generate unintended consequences. Decisions made using only a cost-benefit analysis often include accepting some level of harm, if the decision will otherwise achieve greater outcomes for the firm (Mepham 2000, 2013). In this approach, organizational processes are "ways of extracting more economic value" (Kanter 2011, p. 68) from consumers, and every decision is made in light of its contribution to the firm's financial goals according to the key performance indicators (KPIs) specifically adopted (e.g., profits, market share, return on investment). Consequently, innovations in service design are a means to reach higher levels of profit and financial results (Kurtmollaiev et al. 2018).

Food design has long adopted the economic approach, taking decisions intended to optimize already-existing foods and quickly developing novel products with the lowest possible cost, for greater profitability (Lundahl 2012). To increase the efficiency of the innovation process, food designers largely use predictive algorithms to quantitatively assess the chemical, physical, biological, and nutritional properties of food. Indeed, food design strongly resembles the standard new product development model (Hoyer et al. 2010), focusing on products' ingredients, processes, and observable trends and using market segmentation to gain insights into consumers' wants and needs. As a result, the food industry has traditionally been highly product oriented (Olsen 2015), supporting food innovation approaches focused on product features led by 
engineers and industry experts. For example, corn dogs are tasty and easy to eat on the go and, when introduced to the market, resulted in greater consumption of processed meat deep-fried in vegetable oil (Olsen 2015). Another example is misleading food labels (due to food engineering), which have resulted in processed foods being mistakenly perceived by consumers as medicine that can cure certain medical conditions (Umegaki 2015).

Restricted food design using either the endemic and economic approach is likely to enrich only the principal actors, ignore overall food well-being, and create unintended consequences across the food ecosystem. To reduce the risk of unintended consequences, we propose two novel approaches to food design and provide recommendations for practice. We do so by encouraging the adoption of the systemic (vs. endemic) approach to the innovation process and the ethical (vs. economic) approach to decision-making. Figure 1 presents a comparison of the systemic versus endemic ("design food to make us vs. me rich/healthy") and ethical versus economic ("We vs. I design food") approaches.

\section{- Insert Figure 1 here -}

A systemic (vs. endemic) approach extends the innovation process to include all actors who participate in the ecosystem and to integrate their resources (Vargo and Lusch 2011) into the development of customer-centric experiences (Zomerdijk and Voss 2010). An ethical (vs. economic) approach to decision-making assumes that a meaningful life (i.e., overall well-being) is the ultimate goal (Diener and Seligman 2004). The ethical approach recognizes the moral dimensions of food (Mepham 1996a) and business decisions, including innovation (Freeman, Phillips, and Sisodia 2020). Table 1 shows the application of the systemic and ethical approaches to food design in the "Eat Out to Help Out" case. In the following sections, we first describe the systemic approach and the four ethical principles. Then, we discuss what the novel food 
experience design is and how it contributes to food well-being and its five pillars (see Figure 2)

(Block et al. 2011).

- Insert Table 1 and Figure 2 here -

\section{THE SYSTEMIC APPROACH TO FOOD DESIGN}

Food is a complex ecosystem, a network comprised of and defined by multiple interrelated actors (Baron et al. 2018), but this is not yet completely understood by food designers. Many people think of modern food systems as mainly consisting of linear supply chains built on stable relationships (Baron et al. 2018). For example, a potato goes from the farm to the processor, and the resulting chips go to the warehouse, then the retailer, and ultimately to the consumer. However, this linear concept is overly simplistic, neglecting system dynamics and interrelations and their effects (Helkkula, Kowalkowski, and Tronvoll 2018). Food designers can adopt approaches that integrate multiple stakeholders' needs and perspectives and derive greater value from the full food ecosystem. Key stakeholders include farmers, grocery retailers, and anyone else who has a role in the whole process, even if marginal, such as creditors and the bank system (that sustain farmers and so on), tour operators (that offer thematic food and wine touristic experiences), and the education system (that instructs those who will be in charge for well-being).

Ecosystems are complex constellations of integrated resources in which market and nonmarket stakeholders participate at different levels (Chandler and Lusch 2015; Vargo and Lusch 2011; Vink et al. 2021). In these highly dynamic and complex contexts, stakeholders' actions and interactions, at different times and with different frequencies, generate value (Friend and Malshe 2016; Kelleher et al. 2020; Vargo and Lusch 2004). Through their intertwined relationships, actors participating in the ecosystem cocreate value together (Becker and Jaakkola 2020; Vink et al. 2021). In ecosystems, cocreation is a collective business that includes everyone who generates and consumes value. The systemic approach expands the original view used to identify the 
salient, legitimate stakeholders in a network to include every actor who contributes to cocreating the perceived value (Sudbury-Riley et al. 2020). Thus, ecosystems comprise actors who participate in the value network in some way, regardless of their position in the system, the longevity of their contributions, their roles, their actual or potential contributions to the cocreated value, and whether their interactions with other actors are direct or indirect. Cocreation in ecosystems is not limited to customers and companies; it includes even actors who are generally regarded as marginal.

The systemic approach transforms the restricted food innovation process to leverage the collective and collaborative nature of innovation (Patrício and Fisk 2013; Yu and Sangiorgi 2018). In the recent past, food designers began to increase consumer participation in their design processes, as a strategy to enhance the probability of consumer acceptance and market success (Liedtka 2015; Rosen, Schroeder, and Purinton 1998). Food designers now largely analyze customer experiences and adopt iterative and interactive processes to glean insights into the consumer world (Batat et al. 2017; Olsen 2015). However, having consumers participate in the innovation process is not enough to guarantee that new food experiences will enhance levels of individual and societal well-being. The consumer is only one cocreator in food ecosystems, and designers must recognize the contributions of all the actors who participate in cocreation. The systemic approach expands cocreation to include everyone belonging to the food ecosystem. This is a key implication of our novel food experience design.

In the systemic approach, innovation "transcends the organizational boundaries and is situated in a service ecosystem" (Chandler et al. 2019, p. 76). As no single actor fully controls the value generated in a system (Chandler and Vargo 2011), the success of food innovations results from a collective effort, inviting participation from diverse stakeholders. For example, in 2017, in response to consumer demand, Chipotle, a popular fast-casual Mexican chain, added queso dip to 
its menu. The firm had developed its recipe in accordance with its commitment to avoid artificial ingredients (a key Chipotle value proposition). Unfortunately, the smooth, viscous, Americanstyle queso that consumers expected is impossible to create using only real cheese, and the product flopped. One headline read, "Hate Chipotle queso? Blame Chipotle customers," and the story explained that "Chipotle ... built its brand by catering to customers demanding food both natural and 'authentic.' And that's the rub: Authentic queso is not natural, and natural queso is not authentic" (Hafner 2017). Which consumer requests (natural or authentic) should the food designers have prioritized when both were made explicit and a misstep in either direction would harm the brand? How do farmers react to possible consumer education policies? What is grocery retailers' viewpoint when selling this product and addressing customer complains? Only novel approaches to food design can answer these questions.

As food designers expand their consideration to more and diverse actors in their ecosystems, the likelihood of these types of conflicts (and other, more troubling questions) emerging increases. Therefore, the usefulness of an ethical rubric that designers can follow in decisionmaking also increases (Beauchamp and Childress 2001). Ethical issues inevitably arise when food designers must make practical decisions to prioritize competing stakeholder interests. For example, consumers might prefer unwholesome foods with dangerous consequences for their health but positive effects on their short-term mood. When these interests affect different stakeholders in different areas in an industry, design decisions that benefit one group can result in negative externalities for another. Food experiences even on the demand side might generate well-being for a specific marketing target while having negative effects on other market segments. Similarly, prioritizing competing interests of different generations is a challenge for designers that must identify the long-term effects of their decisions (i.e., predict the needs of future generations of all relevant stakeholders). When scientific competences are limited, failure 
to do so is even more likely, and potentially catastrophic unintended consequences might arise. Long-term effects are also sometimes impossible to detect. In these situations, designers need supportive tools to make decisions. The chocolate industry provides an illustration. Chocolate contains flavonols, antioxidants, and micronutrients, which have been shown to have positive effects on people's bodies, minds, and spirits (Jackson et al. 2019). It is also the world's most popular candy, is believed to be an aphrodisiac since the pre-Columbian era, is incorporated into religious traditions (e.g., in the form of Easter bunnies and eggs), and is simply a delicious treat. This multibillion-dollar industry has emerged over several hundred years. Although the major chocolate-producing companies are American and European, most of the world's cocoa now comes from West Africa. Cocoa plantations have been credibly accused of depredation of protected lands and human rights violations, including the enslavement of child workers (Balch 2021). In short, the production of food that is beneficial for billions of individuals is directly responsible for substantial human suffering and ecological damage. This case emphasizes the importance of integrating ethical principles into a food system's decision-making mechanisms, to understand the system's potential effects on all its stakeholders for its entire duration.

\section{THE FOUR ETHICAL PRINCIPLES APPROACH TO DECISION-MAKING IN FOOD DESIGN}

Humans have been concerned with the moral dimensions of food since ancient times, and such concerns have given rise to the study of food ethics. However, a cursory review of the literature reveals substantial challenges to pursuing ethical principles regarding food production and consumption, despite the call to do so from consumers, activists, industry, and society. Famine is on the rise, as are climate and justice issues, which are urgent and strictly interconnected, and the disparity between the rich and the poor is becoming more relevant in light of the quantity and quality of food available. Food designers have been identified as potential agents of change that 
can reduce products' harmfulness and consumer vulnerability (Smith and Cooper-Martin 1997), as they can provide "acceptable resolutions of moral problems of present and practical urgency" (Callahan 1988, p. 8). However, despite their efforts to follow ostensibly ethical principles, food designers' ability to address these pressing issues has been relatively limited due to the prevalence of utilitarian and economic perspectives in established food systems (Barrett 2006). In a world that treats diverse peoples as a global marketplace, a focus on maximizing economic returns often leads to benefits for some populations but not others. For example, avocado consumption has dramatically increased in the United States, from 436 million pounds in 1985 to 2.6 billion pounds in 2020 , as most U.S. consumers perceive them as a wholesome food with high levels of healthy fats and fibers (Statista 2021). Avocadoes are expensive though, not just in terms of their price tag but also in terms of sustainability. In the long run, avocadoes as a monoculture crop negatively affect biodiversity, overtax water supplies, and contribute to deforestation, global warming, and climate change (Gonçalves 2021). Therefore, the potential to offer better health to some consumers might come at the expense of other people, communities, and ecosystems. Food system design calls for ethical principles and perspectives that link them, to create holistic solutions that benefit all stakeholders in the long run.

Across contexts, and despite lingering questions about the link between medical and everyday-life ethics, the four ethical principles Beauchamp and Childress (2001) established in biomedics more than 40 years ago with the first edition of their book have proved flexible, practical, reliable, and normative for everyday decision-making, especially in challenging and complex situations like those being faced today (Dunfee, Smith, and Ross 1999; National Commission for the Protection of Human Subjects of Biomedical and Behavioral Research 1979). The four principles are as follows:

1. Nonmaleficence: Do no harm. Avoid actions that are counter to people's interests and well- 
being. For example, vitamin E, praised for its antioxidant properties, has proved ineffective in humans but is still widely available in supermarkets and vitamin stores.

2. Beneficence: Do as much good as possible while balancing benefits with risks and costs. For example, while breastfeeding has health benefits for both mothers and children, mothers are still not always supported in breastfeeding.

3. Autonomy: Do not treat people as merely cases. They must be properly informed of their rights and options, and their decisions must be respected. For example, food suppliers should always disclose their products' origins, nutritional content, and other salient information that might affect consumers' health and decision-making.

4. Justice (fairness): Distribute resources, benefits, risks, and costs appropriately or equitably across the population. For example, the availability of nutritious and wholesome foods should not be dependent on individual differences such as a consumer's neighborhood or socioeconomic status.

Mepham's (1996a, 2000, 2013; Mepham et al. 2006) work extends these four principles by defining a ready-to-use ethical matrix. This matrix is a conceptual tool that can guide and support decision-makers as they determine the ethical acceptability and/or optimal regulatory controls for existing or prospective technologies in food and agriculture. It guides users in identifying ethical issues at the intersection of ethical principles and specific relevant interest groups (e.g., consumers, food producers, farm animals, the living environment). The matrix accommodates the collective concerns of the stakeholders interested in food and, as such, has been widely adopted in decision-making contexts. However, despite its obvious contributions, Mepham's matrix is intrinsically limited as an ethical framework because it promotes a utilitarian and particular context-based approach to food design, ignoring the interconnection among human experiences, food ecosystems, and the food well-being of future generations. Current issues characterizing 
food availability, production, and distribution call for innovative solutions that stem from the understanding of the human experience related to food well-being. The novel food experience design is a response to this call.

\section{UNDERSTANDING THE NOVEL FOOD EXPERIENCE DESIGN}

What Is the Novel Food Experience Design?

We build on the four ethical principles approach to food design and the systemic approach to innovation to develop the novel food experience design, which can support designers, policy makers, service providers, researchers, and practitioners whose goal is to develop new food experiences fostering well-being. We define it as follows:

The novel food experience design is an ethical approach to decision-making embedded within a systemic approach to innovation that extends designers' strategic vision in terms of food experiences, legitimate actors, and goals. It fosters customercentric food experiences through three critical steps of innovation: (1) gathering actors' data, (2) cocreating ideas with other actors, and (3) testing ideas in the food ecosystem. The ultimate goal is to promote food well-being.

The novel food experience design is rather consistent with other innovation processes that consist of three basic steps (Liedtka 2015) but are expanded in our framework. The first exploratory step aims to identify user needs and clarify the problem to address. Toward this end, designers gather consumer information and insights, but depending on their goals, they can use different methods and sources and consider different types of consumers and needs. However, our novel framework expands this step by including consumers and anyone else who plays a role in the food ecosystem, such as buyers, gatekeepers, influencers, producers, service suppliers, grocery retailers, and educators. The second step involves idea generation, in which designers 
develop possible creative solutions and concepts. They might work in collaborative teams and even with customers to ideate new solutions. Collaboration enlarges in our novel framework to include every actor in the food ecosystem that contributes to generating, delivering, and consuming value. The third step is idea testing, in which designers adopt different quantitative and qualitative methods, typically prototyping and experimenting, to test new ideas intended to satisfy people's needs. The novel food experience design also expands this final step by testing ideas with any actor in the food ecosystem. Thus, it aims to satisfy the needs of every actor, not just those of consumers.

These three steps are iterative. Our novel food experience design uses the same basic process but adapts and enlarges it to incorporate its systemic and ethical approaches, as we discuss in the following sections.

How Consistent Is a Food Design Strategy with the Novel Food Experience Design?

Our novel food experience design enlarges the strategic vision of food design. Managers who want to apply it need to start with an evaluation of their strategic vision. We present a selfassessment tool for managers who want to understand the extent to which their strategic vision is consistent with the novel food experience design: The less consistent it is, the more likely their food design process is to generate unintended consequences. This evaluation assesses three key elements: the range of food experiences, the range of actors considered legitimate, and the goals being pursued (Figure 3).

\section{-Insert Figure 3 here-}

Range of food experiences. The first element under consideration is how designers treat eating itself. Restricted food design views consumers' food experiences as discrete, unconnected activities; by contrast, the novel food experience design conceptually and experientially integrates consumers' food encounters across multiple journeys and touchpoints (De Keyser et al. 
2020; Lemon and Verhoef 2016). The novel framework also prioritizes the emotional dimensions of food experiences, as understanding the consumer perspective is a driver of product innovation (McColl-Kennedy et al. 2019), especially in the design of experience-centric services (Zomerdijk and Voss 2010).

Range of legitimate actors. The second element pertains to who is considered a stakeholder in the food design process. The novel food experience design adopts an extended view of who the legitimate actors are, both when analyzing the food ecosystem and when cocreating the food experiences. Indeed, while food designers typically respond primarily to the demands of their most potent financial stakeholders, the novel food experience design emphasizes that value is cocreated by all the participants in the food system (Ranjan and Read 2016). Thus, it considers relevant anyone who contributes to either value coproduction (i.e., consumer-firm exchange of physical and mental resources) or value-in-use (i.e., postpurchase consumer evaluation of products based on aptitudes and knowledge). We posit that the consumer-centered novel food experience design value network is more dynamic, open, flexible, resilient, and sustainable than the traditional stakeholder model. Marketing and service research has amply demonstrated the importance of customers in value creation (Sudbury-Riley et al. 2020; Vargo and Lusch 2004), strategic planning (McColl-Kennedy et al. 2019), and the generation of solid financial returns (Hoyer et al. 2010; Kelleher et al. 2020; Melton and Hartline 2010; Trischler et al. 2018). These findings are shown in food-specific studies as well (Liedtka 2015; Olsen 2015).

The novel food experience design acknowledges that all actors in the food system cocreate value and therefore should participate in the design process. In other words, whereas restricted food design relies on one powerful actor's viewpoint or, at best, integrates it with a customer perspective in a dyadic relationship, the novel food experience design forges extended, open, collaborative platforms with multiple actors contributing to the design process. Collaborative 
platforms give actors access to a far greater range of heterogeneous resources (physical, human, organizational, informational, and relational; Edvardsson, Tronvoll, and Gruber 2011) and allow actors to integrate these resources during the design process (Patrício, Gustafsson, and Fisk 2018; Vink et al. 2021).

Goals Pursued. The third key issue distinguishing the novel food experience design from traditional food design is the goals pursued and, consequently, how the value of new food experiences is assessed. Our framework aims to improve food well-being for individuals and communities. Thus, it goes beyond the traditional cost-benefit analysis of food products themselves to examine direct and indirect symbolic and emotional drivers of customer value. The novel food experience design employs relatively new marketing and service research techniques to evaluate the sensorial dimensions of food (Zomerdijk and Voss 2010), its contextual and social dimensions (Patrício and Fisk 2013), and even its unconscious and irrational effects (Zaltman 2003). These innovative approaches enhance research findings attained through traditional methods (Patrício and Fisk 2013), giving designers and decision-makers exceptional insight into consumer experiences (Lemon and Verhoef 2016; Lundahl 2012). This allows them to make meaningful decisions in the service of greater food well-being. The provision of such service is embedded in a long-term vision of managerial results, for which medium- and long-term effects are as important, and often even more important than, the short-term results. How Can Food Designers Apply the Novel Food Experience Design?

Designers who want to adopt the novel food experience design do not need to change their processes; instead, they need to enlarge and enrich them. Figure 4 illustrates how to use the novel food experience design. Specifically, designers must pay attention to four key points:

1. Strategy. Designers need to define what they are designing (food experiences), which legitimate actors to include in the process (actors of the food ecosystem), and what goals 
they want to achieve (food well-being).

2. Innovation process. Designers must go through the enlarged innovation process, step by step. Here, they need to gather actors' insight (not just consumers, but every actor involved in the food ecosystem, such as farmers, grocery retailers, and other stakeholders), generate ideas by cocreating experiences with every actor in the food ecosystem, and, finally, test these ideas in the food ecosystem.

3. Decision-making. Every decision taken in the three innovation steps described previously should be based on the four ethical principles of nonmaleficence, beneficence, autonomy, and justice (Beauchamp and Childress 2001). Indeed, the innovation process requires that designers prioritize conflicting interests and find a balance among all actors involved in the food ecosystem. These decisions should favor solutions that address all four ethical principles. We provide details on using the four ethical principles in the novel framework in the four FPs addressed subsequently.

4. KPIs. Designers need to clearly identify suitable KPIs to measure the results from the standpoint of individual and collective food well-being. These measures should become relevant points of reference not only for the designers but also for anyone working in the same company. Furthermore, designers need to be consistent with the entire ecosystem and to cover every pillar of food well-being (e.g., food availability, food policy, food socialization, food literacy, food marketing).

- Insert Figure 4 here -

\section{FOUR FPs OF THE NOVEL FOOD EXPERIENCE DESIGN}

To develop the novel food experience design, we draw insights from the four ethical principles: nonmaleficence, to identify the unintended negative consequences of new foods and food experiences; beneficence, to provide ideas for positive agents of change in the food system; 
autonomy, to boosts individuals' opportunities to realize food well-being; and fairness, to promote a just and inclusive social perspective. Table 2 explains the four FPs of the novel food experience design and their practical implications.

\section{- Insert Table 2 here -}

FP1: The novel food experience design is nonmaleficent in that it clearly identifies actors in the value network and limits negative externalities for all.

Nonmaleficence, which commonly means to do no harm, finds its historical roots in medical science, in which public health practice primarily benefited from the incorporation of ethical values. Ahmed (2009, p. 567) defines nonmaleficence as "an obligation not to inflict harm on others or make them worse off than they otherwise would have been." Nonmaleficence also means "to strive not to harm a person who is dependent on your actions" (Göerman 2007, p. 55). Given these definitions, the nonmaleficence principle is relevant in the design of food experiences as it encompasses two issues: (1) identifying legitimate actors, including future generations, and (2) analyzing negative externalities. For example, food design thinking has been applied to help tweens eat more fruits and vegetables, but when it focuses on the product rather than the whole experience, unintended consequences may arise, such as the "unhealthy = tasty" intuition (Raghunathan, Naylor, and Hoyer 2006). Considering negative externalities and unintended consequences, nonmaleficence asks designers to analyze the consequences of their actions and avoid negative impacts on the economic, ecological, social, cultural, and individual (e.g., health) dimensions of an innovation's value. For example, plant-based meat substitutes represent a potentially sustainable (and tasty) option for consumers, but their nature as a highly processed food calls for careful consideration of the potential health risks for current and future consumers, as well as an examination of the holistic impact of the manufacturing and production processes required to meet increasing consumer demand (cf. the chocolate and avocado 
production examples). In the case of the "Eat Out to Help Out" scheme, nonmaleficence would ask designers to carefully consider and contain the negative impact on hospitals and the health system and on restaurant workers and patrons.

The importance of a nonmaleficent mindset is clear when considering a situation in which families are encouraged to dine in traditional "upscale" restaurants. A single-actor view privileges business and leisure diners, usually ignoring families with children. However, children dining in restaurants with their families are enculturated to the utilitarian, hedonic, and experiential value of meals that are prepared, served, and eaten relatively slowly outside a home setting (vs. fast food). Therefore, increasing the opportunities for such meals seems admirable on its face; however, an upscale restaurant's decision to expand its customer base to families risks alienating its other patrons and staff, if it does not adopt an ethical (nonmaleficent) approach. Without thoughtful training, service staff are unlikely to cope successfully with heterogeneous guests simultaneously. A cozy dining room, perfect for a couple on a date, would lose its charm if the couple was seated next to a young family. Kitchen staff might feel overburdened, even resentful if asked to modify recipes or add more child-friendly dishes to the menu. The principle of nonmaleficence demands a global analysis of the entire range of activities that create value and target decisions, to design overall food experiences that limit unintended, adverse effects.

FP2: The novel food experience design is beneficent in that it identifies actions able to promote food well-being benefits (at the societal and individual level) for customers and their value network.

The beneficence principle in food experience design identifies actors and analyzes customer value but, in contrast with nonmaleficence, adopts a positive view. If the principle of nonmaleficence makes food designers vigilant to potential negative consequences, beneficence gives them effective and positive tools to address potential negative consequences. Beneficence 
means doing good and helping others, which includes acting with mercy, kindness, charity, altruism, love, benevolence, and humanity (Tsai 1999).

By including the beneficence principle, our framework helps designers integrate marginalized actors in their innovation processes. As in the nonmaleficence example, the adoption of the novel food experience design would identify restaurants as places to enhance food socialization and interactions among the actors. Cocreative activities appealing to multiple generations could be designed and implemented (e.g., a cooking game using small amounts of ingredients from the restaurant's kitchen), improving food well-being by encouraging play, social interaction, and food literacy. Furthermore, the novel food experience design creates opportunities to design environments appropriate for different kinds of restaurant diners, including vulnerable populations. Improving elderly and disabled consumers' physical access to food is an obvious first step, but those with diminished senses of taste and smell also need specific ingredients and recipes to improve their sensory experience and pleasure. Research indicates that focusing on the pleasure of the experience might be the most effective approach for benefiting public health, customers, and companies/restaurants (Cornil and Chandon 2016).

Another example in which beneficence is required is in addressing the global rise in meat consumption. A beneficent approach to food experience design can lead to food innovations such as clean meat grown in labs, replicating the original animal in terms of flavor and texture. Clean and plant-based artificial meats can satisfy the senses and appetites, while improving eaters' nutritional intake, reducing greenhouse gas emissions, limiting other environmental impacts of meat production (e.g., water use), and eliminating animal suffering. Yet another example of beneficence at work is the emergence of mocktails, low-alcohol beers, and alcohol-free bars, which encourage people to indulge in the sensory and social pleasures associated with drinking but without the adverse health and safety consequences, such as alcohol dependence, poor 
judgment, and drunk driving. In the case of "Eat Out to Help Out," a beneficent approach would have had the program's managers collaborate with public-health experts and restaurant managers and employees to design safe, sustainable, pleasurable experiences to benefit Britain's pandemicstressed population.

FP3: The novel food experience design provides autonomy to generate food well-being by facilitating individual responsibilities for and actions toward food choices.

Autonomy is a crucial feature in the relationship between customers and their environment. Autonomy (i.e., self-governance, self-determination, or self-rule) has a long philosophical tradition and is closely related to will, choice, and freedom (Ryan and Deci 2006). Autonomy results in self-determined acts; however, this does not imply the absence of external influences but rather one's assent to external influences or inputs, so that the self must still endorse the action originating from external prompts (Ryan and Deci 2006). Autonomy means that individuals act “(1) intentionally, (2) with understanding, and (3) without controlling influences that determine their action" (Beauchamp and Childress 2001, p. 59). If literacy provides knowledge and competence, autonomy enables competence to take action in the right direction.

When autonomy is low, consumers may not be able to plan healthful meals or may choose unsustainable food options. Furthermore, without autonomy, enjoyment from food experiences is diminished (Hofmans, Gelens, and Theuns 2014). The perceived quality of an experience depends on the person's involvement. For example, food experiences on college campuses that promote autonomy, such as students having access to fresh and wholesome food and spaces where they can cook, socialize, and eat with their friends, leads to enhanced food well-being (Austin 2021). The design of food experiences that respect consumer autonomy starts with a deep understanding of the level of knowledge.

The novel food experience design supports food designers in safeguarding actors' autonomy, 
which is crucial to ensure respect for every individual's situation and leads to greater food wellbeing. For example, in fast-food restaurants and grocery stores, vulnerable people might perceive self-service technologies and kiosks as too challenging to use. However, autonomy-focused designers can integrate user-friendly accessibility tools (e.g., voice recognition) into their kiosks to improve the interaction for all users, regardless of their technological know-how. By incorporating autonomy, the novel food experience design can result in long-term positive changes and sustainable impacts. In the case of "Eat Out to Help Out," a focus on autonomy might have recognized the time consumers spend in queues as an obstacle to the program's success and addressed it by providing consumers with better information and tools to reduce wait times.

FP4: The novel food experience design ensures fairness by emphasizing egalitarian treatment and equal opportunities in food consumption.

Fairness takes into account the need for justice (Mepham et al. 2006; Rawls 1991). Given its essential role in driving human reactions, fairness has received a great deal of attention in management and service research (DeWitt, Nguyen, and Marshall 2008; Schoefer and Diamantopoulos 2008). Fairness consists of three key principles that help remove impartial decisions toward individuals based on their ethnicity, gender, social status, or other traits: (1) the greatest-equals-liberty principle, in which each person has equal access to the most basic rights and liberties; (2) the difference principle, in which even people who are at the edge of a society experience fairness in the long run; and (3) the equal opportunities principle, in which people with similar natural abilities have equal opportunities to the same rights (Rawls 1991).

The absence of fairness in food design has led to food failures in the market, such as food deserts (i.e., places where access to healthful food is limited). The novel food experience design can resolve such market failures by integrating fairness into food design. An example of a 
successful application of food fairness in food retail is Konsum Värmland in Sweden. Konsum Värmland is fair to the environment by reducing waste and energy use, to customers by enhancing product quality, to animals by increasing animal welfare, and to suppliers by using fair-trade products. By incorporating fairness as a core value, the company has also maintained a steady increase in revenue. The novel food experience design also incorporates fairness as a priority to ensure that all involved agents are treated with equity. Value cocreation offers new technology-enabled tools and services that assist designers in uncovering new ideas by leveraging open innovation and mass collaboration (Lundahl 2012), recognizing individual contributions, and then generating "balance, fairness, and harmony" (Freeman, Phillips, and Sisodia 2020, p. 221). In the "Eat Out to Help Out" scheme, a fair approach would not have overlooked lowincome people as potential beneficiaries; instead, it would have ensured that people at all income levels, not just the middle-class and wealthy, benefited from a tax-subsidized program designed to increase happiness and food well-being.

THE OUTCOME OF THE NOVEL FOOD EXPERIENCE DESIGN: FOOD WELLBEING

Improving consumer well-being has become a top priority for service scholars (Ostrom et al. 2010) and has emerged in recent years as the ultimate goal in myriad industries (e.g., Berry and Bendapudi 2007; Martin and Hill 2015). Food is no exception. Given the "positive psychological, physical, emotional, and social relationship with food at both the individual and societal levels" (Block et al. 2011, p. 9), food well-being is one of the ultimate goals of any food experience (Bublitz et al. 2019; Scott and Vallen 2019).

The four ethical design principles of the novel food experience design increase food wellbeing through the five pillars of food well-being (Block et al. 2011): food availability, food policy, food socialization, food literacy, and food marketing. A broad range of measures is 
necessary to assess such a wide spectrum of interrelated effects, but a valid and reliable set of measures is still lacking. Thus, managers could assess the impact of their designed food experiences through individuals' perceptions of each pillar of food well-being, as proposed in Table 3. Each of the four ethical design principles under our novel framework helps develop innovative food experiences that increase overall individual well-being and minimize disparities in society or unsustainable practices.

- Insert Table 3 here -

\section{Designing Nonmaleficent Food Experiences for Food Well-Being}

The ethical principle of nonmaleficence, or do no harm, applied to food experience helps reduce the probability of unintended consequences. For example, according to Block et al. (2011), Western society fights global hunger by providing food to impoverished people, but these efforts generate the unintended consequence of obesity. Designers who adopt our framework can practice nonmaleficence to gain a broader understanding of the consequences of food production and consumption processes, shape food and taste preferences, build on the effects of information on the consumption side, help make the entire food ecosystem — not just the supply chainsustainable, and enhance the marketing returns of sustainable food.

\section{Designing Beneficent Food Experiences for Food Well-Being}

The ethical principle of beneficence calls for positive actions of an actor that outweigh potential harms to and benefit others. Beneficent approaches carefully consider how to improve food availability, increase the range of actors involved, and reduce the use and impact of toxic chemicals in food production. They also encourage designers to customize the content information for each actor involved in the food system, offer customized socialization to specific targets, and provide suggestions for customized food marketing strategies and policies. These are 
all factors that managers should consider when assessing the success of their designed food experiences.

\section{Designing Autonomous Food Experiences for Food Well-Being}

The novel framework ensures autonomy for all actors by identifying and empowering them within and throughout all stages of the food experience. In particular, the novel food experience design suggests the design of autonomous food experiences in each of the five pillars of food well-being. For example, it should grant consumers access to a broad range of resources. Increased resources improve people's autonomy over their choice of food experiences, thus enhancing food availability. Ensuring autonomy in food experience design is especially important for vulnerable consumers, who might need greater access or additional resources or who might not have sufficient food literacy. Focusing on consumer autonomy can even help provide protection against predatory and other unethical marketing practices. A focus on autonomy strengthens trust in the self by promoting consumers' skills and confidence.

\section{Designing Fair Food Experiences for Food Well-Being}

Fairness refers to the just distribution of resources among all individuals in society so that outcomes among different people are equitable. Thus, the novel food experience design emphasizes fairness and justice as priorities when developing food experiences to enhance food well-being. For example, by respecting justice, the design generates food experiences that reduce inequality of resources in the food system, thus increasing food availability. Our framework supports the promotion of local food production, leading to higher levels of economic and social inclusion. It offers opportunities for food well-being to everyone regardless of social or economic status, encourages socialization, and provides all individuals with enhanced education and resources as well as opportunities to use them. Finally, the novel food experience design helps 
designers develop food marketing that avoids unsavory consequences for particular individuals or groups.

\section{DISCUSSION}

\section{Managerial Implications for Service Research and Practice}

Our novel framework supports managers in food design. It increases the performance of the entire ecosystem by way of actor engagement, which is "a dynamic and iterative process, reflecting actors' dispositions to invest resources in their interactions with other connected actors in a service system" (Brodie et al. 2019, p. 183). Actor engagement extends the customer engagement concept to include any individual, group, organization, or technology within the service ecosystem. By increasing actor engagement, managers adopt a participatory approach that improves actors' dispositions and connections in a dynamic relationship, generating benefits for the entire food system. Kelleher et al. (2020) show that the contribution of a wide range of interdependent actors is critical because, if well-coordinated, they create higher levels of overall well-being. The novel food experience design supports the coordination of these actors by strengthening their contributions, leading to a greater probability of success of innovative food designs.

Beyond specific food experiences they design, organizations that adopt our novel framework may increase their market performance. Perceived fairness, democracy, transparency, and responsiveness to consumers' needs are relevant drivers of brand equity and a potential source of sustainable competitive advantage. Indeed, marketing literature has long established that consumers appreciate these aspects related to firms' social impact (Serafeim 2020), and recent turbulences such as the COVID-19 pandemic, the Black Lives Matter movement, and the climate crisis have even raised their relevance for markets and marketers (Rodríguez-Vilá et al. 2020). Such social factors are a relevant differentiating strategy. Both customers and managers 
consider fairness and just outcomes when evaluating service failures and subsequent recovery (McColl-Kennedy and Sparks 2003), and perceptions of unethical decisions and behaviors can result in lost sales and consumer loyalty. The principles of our framework can be applied at any stage of the food design process; as a key driver of market performance, ethical principles should inform and inspire decision-making. The novel food experience design situates ethical principles at the core of the design process, rather than an afterthought, as is currently the norm (Beauchamp and Childress 2001; McColl-Kennedy and Sparks 2003). In honestly and forthrightly addressing different stakeholders' competing interests and values, the novel food experience design provides a participatory tool for decision-making, and adopting an ethics-based approach increases the transparency of the process and democratic pluralism. Thus, the novel food experience design helps advance transformative social change. "Social and ethical transformation in personal values" (Ikerd 2019, p. 374) is the key ingredient to make a fundamental, systemic change, and the novel food experience design answers the call of sustainability scholars for dramatically changed food systems.

\section{Limitations and Future Research Directions}

Our novel framework is reasonably practical; indeed, philosophers have long recognized the power of applying ethics to practical issues. According to Singer (1993, p. 2), "an ethical judgment that is no good in practice must suffer from a theoretical defect as well, for the whole point of ethical judgments is to guide practice." The novel food experience design can help designers and managers identify the most morally justifiable and fairest range of solutions to the challenges they face. Thus, food designers can prioritize stakeholders' concerns and make difficult but moral decisions based on sound reasoning. However, we recognize that the novel food experience design leaves some questions unanswered. For example, who or what defines "sound reasoning"? What is the value of time? What is the role of scarce information? Can food 
designers define what is morally acceptable without referring to the four ethical principles? Do stakeholders' level of importance, power, and legitimation affect their relevance? How should the strategic target decisions change? Are consumers willing to work toward their well-being? Are scientists ready to identify long-term effects? These questions open new areas of inquiry that future research can address.

In addition, although our study synthesizes accumulated knowledge, several issues need further advancement. The four FPs and our general definition of the novel food experience design serve as the foundation for future work (Table 4). Each of the four FPs engenders a specific set of research problems that innovative research can address to extend the implications of our framework to other sectors and research fields. All four aspects offer a foundation for further exploration.

- Insert Table 4 here -

In conclusion, the novel food experience design leads to high levels of individual and communal food well-being by promoting innovative food experiences while leveraging ethical principles (i.e., nonmaleficence, beneficence, autonomy, and fairness) and proposing a roadmap that limits unintended negative consequences, generates positive externalities, enables consumer autonomy, and makes the food system fairer. Ethics indicate where society needs to go if it wants to enhance well-being - but that is a different story.

\section{References}

Addis, Michela and Morris B. Holbrook (2019), "From Food Services to Food Experiences. Eating, Well-being, and Marketing," in Food and Experiential Marketing: Pleasure, Wellbeing and Consumption, Wided Batat, ed. Oxon: Routledge, 16-37. 
Ahmed, Haitham M. (2009), “Obesity, Fast Food Manufacture, and Regulation: Revisiting Opportunities for Reform," Food and Drug Law Journal, 64 (3), 565-576.

Austin, Caroline Graham (2021), "The History of Design Thinking and its Contributions to Food Experiences and Well-Being," in Design Thinking for Food Well-Being: Creating Innovative Food Experiences, Wided Batat, ed. Cham: Springer, 19-33.

Balch, Oliver (2021), "Mars, Nestle and Hershey to Face Child Slavery Lawsuit in US," The Guardian, February 12, (accessed on May 19, 2021), [available at https://www.theguardian.com/global-development/2021/feb/12/mars-nestle-and-hershey-toface-landmark-child-slavery-lawsuit-in-us].

Baron, Steve, Anthony Patterson, Roger Maull, and Gary Warnaby (2018), "Feed People First: A Service Ecosystem Perspective on Innovative Food Waste Reduction," Journal of Service Research, 21 (1), 135-150.

Barrett, Christopher (2006), “Food Aid's Intended and Unintended Consequences,” Agricultural and Development Economics Division of the Food and Agriculture Organization of the United Nations (FAO - ESA), ESA Working Paper 06-05.

Batat, Wided (2019), "Introduction to the Experiential Pleasure of Food," in Food and Experiential Marketing: Pleasure, Well-Being and Consumption, Batat Wided, ed. Oxon: Routledge, 1-15.

Batat, Wided, Paula C. Peter, Handan Vicdan, Valeria Manna, Ebru Ulusoy, Emre Ulusoy, and Soonkwan Hong (2017), “Alternative Food Consumption (AFC): Contributions to Food WellBeing (FWB), Marketing, and Public Policy Amongst Low SES Consumer”, Journal of Marketing Management, 33, 580-601.

BBC (2020), "Eat Out to Help Out: Diners Claim 100 Million Meals in August” (accessed December 28, 2020), [available at https://www.bbc.com/news/business-54015221]. 
Beauchamp, Tom L. and James F. Childress (2001), Principles of Biomedical Ethics, 5th ed. New York: Oxford University Press.

Beck, Ulrich (1997), The Reinvention of Politics: Rethinking Modernity in the Global Social Order, Cambridge: Polity.

Becker, Larissa and Elina Jaakkola (2020), “Customer Experience: Fundamental Premises and Implications for Research," Journal of the Academy of Marketing Science, 48 (4), 630-648.

Berry, Leonard L. and Neeli Bendapudi (2007), “Health Care: A Fertile Field for Service Research,' Journal of Service Research, 10 (2), 111-122.

Block, Lauren G., Sonya A. Grier, Terry L. Childers, Brennan Davis, Jane E.J. Ebert, Shiriki Kumanyika, et al. (2011), "From Nutrients to Nurturance: A Conceptual Introduction to Food Well-Being," Journal of Public Policy \& Marketing, 30 (1), 5-13.

Brodie, Roderick J., Julia A. Fehrer, Elina Jaakkola, and Jodie Conduit (2019), “Actor Engagement in Networks: Defining the Conceptual Domain," Journal of Service Research, 22 (2), 173-188.

Bublitz, Melissa G., Jonathan Hansen, Laura A. Peracchio, and Sherrie Tussler (2019), “Hunger and Food Well-Being: Advancing Research and Practice," Journal of Public Policy \& Marketing, 38 (2), 136-153.

Bublitz, Melissa G., Laura A. Peracchio, Alan R. Andreasen, Jeremy Kees, Blair Kidwell, Elizabeth Gelfand Miller, et al. (2011), “The Quest for Eating Right: Advancing Food WellBeing," Journal of Research for Consumers, 19, 1-12.

Callahan, Joan C. (1988), Ethical Issues in Professional Life. New York: Oxford University Press.

Chandler, Jennifer D., Ilias Danatzis, Carolin Wernicke, Melissa Archpru Akaka, and David Reynolds (2019), “How Does Innovation Emerge in a Service Ecosystem?” Journal of Service 
Research, 22 (1), 75-89.

Chandler, Jennifer D. and Robert F. Lusch (2015), "Service Systems: A Broadened Framework and Research Agenda on Value Propositions, Engagement, and Service Experience," Journal of Service Research, 18 (1), 6-22.

Chandler, Jennifer D. and Stephen L. Vargo (2011), “Contextualization and Value-in-Context: How Context Frames Exchange," Marketing Theory, 11 (1), 35-49.

Cornil, Yann and Pierre Chandon (2016), "Pleasure as a Substitute for Size: How Multisensory Imagery Can Make People Happier with Smaller Food Portions," Journal of Marketing Research, 53 (5), 847-864.

De Keyser, Arne, Katrien Verleye, Katherine N. Lemon, Timothy L. Keiningham, and Philipp Klaus (2020), "Moving the Customer Experience Field Forward: Introducing the Touchpoints, Context, Qualities (TCQ) Nomenclature," Journal of Service Research, 23 (4), 433-455.

DeWitt, Tom, Doan T. Nguyen, and Roger Marshall (2008), “Exploring Customer Loyalty Following Service Recovery: The Mediating Effects of Trust and Emotions," Journal of Service Research, 10 (3), 269-281.

Diener, Ed and Martin E. P. Seligman (2004), "Beyond Money: Toward and Economy of WellBeing," Psychological Science in the Public Interest, 5 (1), 1-31.

Dunfee, Thomas W., N. Craig Smith, and William T. Ross Jr. (1999), "Social Contracts and Marketing Ethics," Journal of Marketing, 63 (3), 14-32.

Edvardsson, Bo, Bård Tronvoll, and Thorsten Gruber (2011), "Expanding Understanding of Service Exchange and Value Co-Creation: A Social Construction Approach," Journal of the Academy of Marketing Science, 39 (2), 327-339.

Fetzer, Thiemo (2020), "Subsidizing the Spread of COVID19: Evidence from the UK's Eat-Outto-Help-Out scheme," CAGE working paper no. 517 (accessed December 28, 2020), 
[available at

https://warwick.ac.uk/fac/soc/economics/research/centres/cage/manage/publications/wp.517.2 020.pdf].

Freeman, R. Edward, Robert Phillips, and Rajendra Sisodia (2020), "Tensions in Stakeholder Theory," Business \& Society, 59 (2), 213-231.

Friend, Scott B. and Avinash Malshe (2016), “Key Skills for Crafting Customer Solutions within an Ecosystem: A Theories-in-Use Perspective,” Journal of Service Research, 19 (2), 174-191.

Göerman, Ulf (2007), “Some Ethical Issues Raised by Personalized Nutrition,” Genes and Nutrition, 2 (1), 55-58.

Gonçalves, André (2021), “Avocado Sustainability: What Are the Social and Environmental Impacts of Avocados?” Youmatter, (accessed May 12, 2021), [available at https://youmatter.world/en/benefits-avocados-production-bad-people-planet-27107/].

Hafner, Josh (2017), “Hate Chipotle Queso? Blame Chipotle Customers,” USA Today, September 21, (accessed on May 19, 2021), [available at https:/www.usatoday.com/story/money/nationnow/2017/09/21/hate-chipotle-queso-blame-chipotle-customers/686195001/].

Helkkula, Anu, Christian Kowalkowski, and Bård Tronvoll (2018), “Archetypes of Service Innovation: Implications for Value Cocreation," Journal of Service Research, 21 (3), 284-301. HM Revenue \& Customs (2020), "Eat Out to Help Out Statistics Commentary” (accessed December 28, 2020), [available at https:/www.gov.uk/government/publications/eat-out-tohelp-out-statistics/eat-out-to-help-out-statistics-commentary].

Hofmans, Joeri, Jolyn Gelens, and Peter Theuns (2014), “Enjoyment as a Mediator in the Relationship Between Task Characteristics and Work Effort: An Experience Sampling Study," European Journal of Work and Organizational Psychology, 23 (5), 693-705. 
Hoyer, Wayne D., Rajesh Chandy, Matilda Dorotic, Manfred Krafft, and Siddharth S. Singh (2010), "Consumer Cocreation in New Product Development," Journal of Service Research $13(3), 283-296$.

Ikerd, John (2019), “An Alternative Future for Food and Farming,” in In Defense of Farmers. The Future of Agriculture in the Shadow of Corporate Power, Jane W. Gibson and Sara E. Alexander, eds., Lincoln: University of Nebraska Press, 363-405.

Jackson, Sarah E., Lee Smith, Joseph Firth, Igor Grabovac, Pinar Soysal, Ai Koyanagi, et al. (2019), "Is There a Relationship Between Chocolate Consumption and Symptoms of Depression? A Cross Sectional Survey of 13,626 US Adults," Depression and Anxiety, 36 (10), 987-995.

Kanter, Rosabeth Moss (2011), "How Great Companies Think Differently," Harvard Business Review, 89 (11), 66-78.

Kelleher, Carol, Deirdre O'Loughlin, Johanna Gummerus, and Lisa Peñaloza (2020), "Shifting Arrays of a Kaleidoscope: The Orchestration of Relational Value Cocreation in Service Systems," Journal of Service Research, 23 (2), 211-228.

Kurtmollaiev, Seidali, Annita Fjuk, Per Egil Pedersen, Simon Clatworthy, and Knut Kvale (2018), “Organizational Transformation Through Service Design: The Institutional Logics Perspective," Journal of Service Research, 21 (1), 59-74.

Lemon, Katherine N. and Peter C. Verhoef (2016), “Understanding Customer Experience throughout the Customer Journey," Journal of Marketing, 80 (6), 69-96.

Levitt, Steven D. and John List (2008), “Economics: Homo Economicus Evolves," Science, 319 (5865), 909-910.

Lewis, Marc (2021), “The Case for Meal Kits: Environment’s Friend or Foe?” EcoWatch, (accessed May 14, 2021), [available at https://www.ecowatch.com/case-for-meal-delivery- 
kits-2650927816.html].

Liedtka, Jeanne (2015), "Perspective: Linking Design Thinking with Innovation Outcomes Through Cognitive Bias Reduction," Journal of Product Innovation Management, 32, 925938.

Lundahl, David (2012), Breakthrough Food Product Innovation Through Emotions Research. London: Academic Press.

MacKenzie, Scott B. (2003), "The Dangers of Poor Construct Conceptualization,” Journal of the Academy of Marketing Science, 31 (3), 323-326.

Martin, Kelly D. and Ronald P. Hill (2015), "Saving and Well-Being at the Base of the Pyramid: Implications for Transformative Financial Services Delivery," Journal of Service Research, 18 (3), 405-421.

McColl-Kennedy, Janet R. and Beverley A. Sparks (2003), “Application of Fairness Theory to Service Failures and Service Recovery," Journal of Service Research, 5 (3), 251-266.

McColl-Kennedy, Janet R., Mohamed Zaki, Katherine N. Lemon, Florian Urmetzer, and Andy Neely (2019), “Gaining Customer Experience Insights that Matter," Journal of Service Research, $22(1), 8-26$.

Melton, Horace L. and Michael D. Hartline (2010), “Customer and Frontline Employee Influence on New Service Development Performance," Journal of Service Research, 13 (4), 411-425. Mepham, Ben (1996a), "Ethical Analysis of Food Biotechnologies: An Evaluative Framework," in Food Ethics, Ben Mepham, ed. New York: Routledge, 101-119.

Mepham, Ben (1996b), "Ethical Issues in Agricultural and Food Research Policy," in Food Ethics, Ben Mepham, ed. New York: Routledge, 154-169.

Mepham, Ben (2000), “The Role of Food Ethics in Food Policy," Proceedings of the Nutrition Society, 59 (4), 609-618. 
Mepham, Ben (2013), "Ethical Principles and the Ethical Matrix," in Practical Ethics for Food Professionals: Ethics in Research, Education and the Workplace, J. Peter Clark and Christopher Ritson, eds. Chichester: Wiley-Blackwell, 39-56.

Mepham, Ben, Matthias Kaiser, Erik Thorstensen, Sandy Tomkins, and Kate Millar (2006), Ethical Matrix Manual. The Haugue: LEI, Onderdeel van Wageningen UR.

Merton, Robert K. (1936), "The Unanticipated Consequences of Purposive Social Action," American Sociological Review, 1 (6), 894-904.

National Commission for the Protection of Human Subjects of Biomedical and Behavioral Research (1979), “The Belmont Report: Ethical Principles and Guidelines for the Protection of Human Subjects of Research,” DHEW Publication No. (OS) 78-0014, (accessed November 3, 2019), [available at https://videocast.nih.gov/pdf/ohrp_appendix_belmont_report_vol_2.pdf].

Olsen, Nina Veflen (2015), "Design Thinking and Food Innovation," Trends in Food Science \& Technology, 41 (2), 182-187.

Ostrom, Amy L., Mary J. Bitner, Stephen W. Brown, Kevin A. Burkhard, Michael Goul, Vicki Smith-Daniels, et al. (2010), "Moving Forward and Making a Difference: Research Priorities for the Science of Service," Journal of Service Research, 13 (1), 4-36.

Patrício, Lia and Raymond P. Fisk (2013), "Creating New Services," in Serving Customers Globally: Global Services Marketing Perspectives, L. Patrício, R.P. Fisk, R. Russell-Bennett, and L.C. Harris, eds. Melbourne: Tilde University Press, 185-207.

Patrício, Lia, Anders Gustafsson, and Raymond Fisk (2018), “Upframing Service Design and Innovation for Research Impact," Journal of Service Research, 21 (1), 3-16.

Pettinger, Tejvan (2019), "Pros and Cons of Fat Tax," (accessed May 13, 2021), [available at https://www.economicshelp.org/blog/5056/economics/pros-and-cons-of-fat-tax/]. 
Pirson, Michael A. and Paul R. Lawrence (2010), "Humanism in Business-Towards a Paradigm Shift?" Journal of Business Ethics, 93 (4), 553-565.

Raghunathan, Rajagopal, Rebecca Walker Naylor, and Wayne D. Hoyer (2006), "The Unhealthy $=$ Tasty Intuition and Its Effects on Taste Inferences, Enjoyment, and Choice of Food Products," Journal of Marketing, 70 (4), 170-184.

Ranjan, Kumar Rakesh and Stuart Read (2016), "Value Co-creation: Concept and Measurement," Journal of the Academy of Marketing Science, 44 (3), 290-315.

Rawls, John (1991), “Justice as Fairness: Political not Metaphysical,” in Equality and Liberty, J.A. Corlett, ed. London: Palgrave Macmillan, 145-173.

Rodríguez-Vilá, Omar, Sundar Bharadwaj, Neil A. Morgan, and Shubu Mitra (2020), "Is Your Marketing Organization Ready for What's Next?" Harvard Business Review, NovemberDecember, 104-113.

Rosen, Deborah E., Jonathan E. Schroeder, and Elizabeth F. Purinton (1998), “Marketing High Tech Products: Lessons in Customer Focus from the Marketplace," Academy of Marketing Science Review, 6, 1-17.

Ross, W. D. (1930), The Right and the Good. Oxford: Oxford University Press.

Ryan, Richard M. and Edward L. Deci (2006), "Self-Regulation and the Problem of Human Autonomy: Does Psychology Need Choice, Self-Determination, and Will?” Journal of Personality, 74 (6), 1557-1586.

Schoefer, Klaus and Adamantios Diamantopoulos (2008), "The Role of Emotions in Translating Perceptions of (In)Justice into Postcomplaint Behavioral Responses," Journal of Service Research, 11 (1), 91-103. 
Scott, Maura L. and Beth Vallen (2019), "Expanding the Lens of Food Well-Being: An Examination of Contemporary Marketing, Policy, and Practice with an Eye on the Future," Journal of Public Policy and Marketing, 38 (2), 127-135.

Serafeim, George (2020), “Social-Impact Efforts That Create Real Value," Harvard Business Review, 98 (5), 38-48.

Singer, Peter (1993), Practical Ethics, 2d ed. Cambridge: Cambridge University Press.

Skålén, Per, Johanna Gummerus, Catharina von Koskull, and Peter R. Magnusson (2015), "Exploring Value Propositions and Service Innovation: A Service-Dominant Logic Study," Journal of the Academy of Marketing Science, 43 (2), 137-158.

Smith, N. Craig and Elizabeth Cooper-Martin (1997), "Ethics and Target Marketing: The Role of Product Harm and Consumer Vulnerability," Journal of Marketing, 61 (3), 1-20.

Statista (2021), "Domestic Avocado Consumption in the United States from 1985 to 2020," (accessed May 12, 2021), [available at https://www.statista.com/statistics/591263/averageavocado-consumption-us-per-week/].

Sudbury-Riley, Lynn, Philippa Hunter-Jones, Ahmed Al-Abdin, Daniel Lewin, and Mohabir V. Naraine (2020), “The Trajectory Touchpoint Technique: A Deep Dive Methodology for Service Innovation,” Journal of Service Research, 23 (2), 229-251.

Thaler, Richard H. (2000), “From Homo Economicus to Homo Sapiens,” Journal of Economic Perspectives, 14 (1), 133-141.

Trischler, Jacob, Simon J. Pervan, Stephen J. Kelly, and Don R. Scott (2018), “The Value of Codesign: The Effect of Customer Involvement in Service Design Teams," Journal of Service Research, 21 (1), 75-100.

Tsai, Daniel F. (1999), “Ancient Chinese Medical Ethics and the Four Principles of Biomedical Ethics," Journal of Medical Ethics, 25 (4), 315-321. 
Umegaki, Keizo (2015), "Positive and Negative Aspects of Food with Health Claims in Japan," Journal of Nutritional Science, 6, S133-5.

Vargo, Stephen L. and Robert F. Lusch (2004), "Evolving to a New Dominant Logic for Marketing," Journal of Marketing, 68 (1), 1-17.

Vargo, Stephen L. and Robert F. Lusch (2011), "It's All B2B ... and Beyond: Toward a Systems Perspective of the Market,” Industrial Marketing Management, 40 (2), 181-187.

Vink, Josina, Kaisa Koskela-Huotari, Bård Tronvoll, Bo Edvardsson, and Katarina WetterEdman (2021), “Service Ecosystem Design: Propositions, Process Model, and Future Research Agenda," Journal of Service Research, 24 (2), 168-186.

Yu, Eun and Daniela Sangiorgi (2018), "Service Design as an Approach to Implement the Value Cocreation Perspective in New Service Development," Journal of Service Research, 21 (1), 40-58.

Zaltman, Gerald (2003), How Customers Think: Essential Insights into the Mind of the Market. Boston: Harvard Business Press.

Zampollo, Francesca (2016), "Welcome to Food Design," International Journal of Food Design, $1(1), 3-9$.

Zomerdijk, Leonieke G. and Christopher A. Voss (2010), “Service Design for ExperienceCentric Services," Journal of Service Research, 13 (1), 67-82. 
Table 1. The Systemic and Ethical Approaches to Food Design in the "Eat Out to Help Out" Case.

\begin{tabular}{|c|c|c|c|}
\hline \multicolumn{2}{|c|}{ Innovation Process } & \multicolumn{2}{|c|}{ Decision-Making } \\
\hline \multicolumn{2}{|c|}{ Who participates in food design? } & \multicolumn{2}{|c|}{ How should decisions be taken in food design? } \\
\hline Endemic approach & Systemic approach & Economic approach & Ethical approach \\
\hline $\begin{array}{l}\text { Salient actors (with high } \\
\text { power of influence, } \\
\text { legitimacy, and urgent } \\
\text { interests) should be } \\
\text { considered. }\end{array}$ & $\begin{array}{l}\text { All those who participate in } \\
\text { the food system should be } \\
\text { considered and should take } \\
\text { part in the value cocreation } \\
\text { process. }\end{array}$ & $\begin{array}{l}\text { Decisions are taken based } \\
\text { on costs, revenues, and } \\
\text { profits. }\end{array}$ & $\begin{array}{l}\text { Decisions are taken based } \\
\text { on their level of } \\
\text { nonmaleficence, } \\
\text { beneficence, autonomy, } \\
\text { and fairness. }\end{array}$ \\
\hline $\begin{array}{l}\text { These include: } \\
\text { - } \quad \text { Restaurant owners } \\
\text { - Chain restaurants } \\
\text { - } \quad \text { Consumers }\end{array}$ & 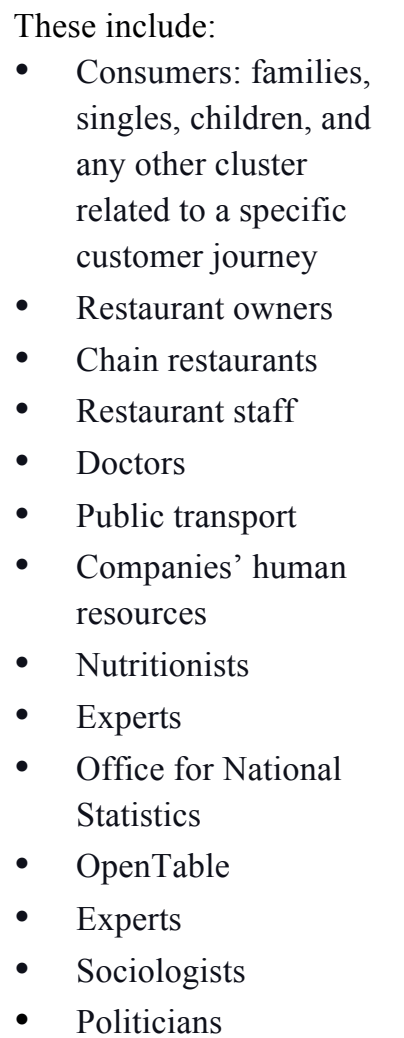 & $\begin{array}{l}\text { Success is measured by } \\
\text { economic returns } \\
\text { generated for key } \\
\text { stakeholders. }\end{array}$ & $\begin{array}{l}\text { Success is measured by the } \\
\text { individual and societal } \\
\text { food well-being generated. }\end{array}$ \\
\hline
\end{tabular}


Table 2. FP Don'ts and Dos.

\begin{tabular}{|c|c|c|}
\hline$F P$ & $\begin{array}{c}\text { Don'ts } \\
\text { Do not believe that ... }\end{array}$ & $\begin{array}{c}\text { Dos } \\
\text { Do believe that .... }\end{array}$ \\
\hline 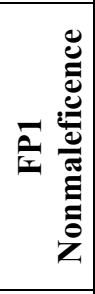 & $\begin{array}{l}\text { - A single-actor perspective is enough. } \\
\text { - The mainstream profiles and actors are } \\
\text { sufficient. } \\
\text { - The food-centric approach is correct. }\end{array}$ & $\begin{array}{l}\text { - You need a multiple-actor perspective, including even } \\
\text { marginal actors negatively affected. } \\
\text { - A balance between different consumers' profiles is } \\
\text { successful. } \\
\text { - Food experience-centric approach is king. } \\
\text { - Food experience offerings must be integrated. }\end{array}$ \\
\hline ڤิ) & $\begin{array}{l}\text { - Consumers with physical disabilities are the } \\
\text { only ones deserving protection. } \\
\text { - Food experiences must be exclusive. } \\
\text { - Disabilities are visible. } \\
\text { - Only experts with similar knowledge } \\
\text { collaborate. }\end{array}$ & $\begin{array}{l}\text { - You need a multistakeholder view, including even } \\
\text { marginal actors positively affected, starting with the } \\
\text { most vulnerable or hidden actors. } \\
\text { - There are different vulnerabilities and disabilities. } \\
\text { - Collaboration with professionals from other industries is } \\
\text { useful. } \\
\text { - You need transformative service practices. }\end{array}$ \\
\hline 饣) & $\begin{array}{l}\text { - Providing people with multiple information } \\
\text { means informing them. } \\
\text { - A single stakeholder is enough. } \\
\text { - Actors' competencies and knowledge are } \\
\text { useless. } \\
\text { - You are the expert. } \\
\text { - You know what people want. }\end{array}$ & $\begin{array}{l}\text { - All stakeholders involved must be recognized and } \\
\text { included. } \\
\text { - You need to know their competences and requirements. } \\
\text { - Everyone's customer journey must be free of coercion } \\
\text { and rich in information, autonomy, and two-way } \\
\text { communication. } \\
\text { - A deep understanding of the context of the food } \\
\text { experiences is the starting point. } \\
\text { - The extent of the company's control over the food } \\
\text { experience deserves your attention. }\end{array}$ \\
\hline 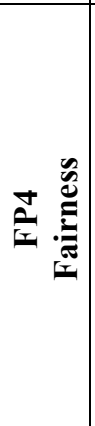 & $\begin{array}{l}\text { - The food product is king. } \\
\text { - The most salient stakeholder is the most } \\
\text { important. } \\
\text { - Success is profit. }\end{array}$ & $\begin{array}{l}\text { - All actors involved in the food experience must be } \\
\text { recognized. } \\
\text { - Fairness should be at the core of the food experience. } \\
\text { - All actors must be treated with balance, fairness, and } \\
\text { harmony. } \\
\text { - Actors in the food ecosystem must be at the same level. } \\
\text { - Every actor should be involved, valued, and promoted } \\
\text { through activities organized. } \\
\text { - The perceived value generated is relevant. }\end{array}$ \\
\hline
\end{tabular}


Table 3. The Novel Food Experience Design Contributions to Food Well-Being: A Format of a Possible Questionnaire.

\begin{tabular}{|c|c|c|c|c|}
\hline$F P$ & $\begin{array}{c}\boldsymbol{F P 1} \\
\text { (Nonmaleficence) }\end{array}$ & FP2 (Beneficence) & FP3 (Autonomy) & FP4 (Fairness) \\
\hline 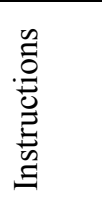 & \multicolumn{4}{|c|}{$\begin{array}{l}\text { Think about the food experience you have designed. For each pillar of food well-being and each question, } \\
\text { report how much the designed food experience contributes to generating food well-being using the scale } \\
\text { below. Select a number from } 1 \text { to } 5 \text { to indicate the extent to which the designed food experience } \\
\text { contributes to... (1 = "to an extremely small extent," } 5 \text { = "to an extremely large extent"). } \\
\text { To what extent does the designed food experience contribute to ... }\end{array}$} \\
\hline 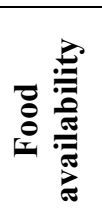 & $\begin{array}{l}\text { promoting local and } \\
\text { organic foods, } \\
\text { especially } \\
\text { considering food } \\
\text { deserts? }\end{array}$ & $\begin{array}{l}\text { promoting healthful } \\
\text { eating? }\end{array}$ & $\begin{array}{l}\text { ensuring actual and perceived } \\
\text { access to food profusion? }\end{array}$ & $\begin{array}{l}\text { ensuring equal access } \\
\text { to healthful food by all } \\
\text { classes of consumers? }\end{array}$ \\
\hline 륭 & $\begin{array}{l}\text { battling agricultural } \\
\text { waste management? }\end{array}$ & $\begin{array}{l}\text { expanding the } \\
\text { interpretation of } \\
\text { stakeholders? }\end{array}$ & $\begin{array}{l}\text { implementing policies that } \\
\text { encourage/promote rather than } \\
\text { limit/punish? }\end{array}$ & $\begin{array}{l}\text { treating everyone } \\
\text { fairly? }\end{array}$ \\
\hline 芯 & $\begin{array}{l}\text { creating a better } \\
\text { balance between } \\
\text { parental control and } \\
\text { food pleasure? }\end{array}$ & $\begin{array}{l}\text { developing social } \\
\text { connections? }\end{array}$ & $\begin{array}{l}\text { developing individual self- } \\
\text { trust? }\end{array}$ & $\begin{array}{l}\text { creating a participative } \\
\text { culture? }\end{array}$ \\
\hline تृ & $\begin{array}{l}\text { driving self- } \\
\text { indulgent } \\
\text { behaviors? }\end{array}$ & $\begin{array}{l}\text { providing relevant } \\
\text { information for } \\
\text { customers? }\end{array}$ & $\begin{array}{l}\text { identifying current literacy } \\
\text { skills of every actor? }\end{array}$ & $\begin{array}{l}\text { providing } \\
\text { servicescapes with } \\
\text { information at all } \\
\text { consumer literacy } \\
\text { levels? }\end{array}$ \\
\hline 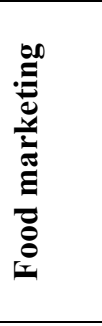 & $\begin{array}{l}\text { assessing the impact } \\
\text { of experiential } \\
\text { marketing on } \\
\text { customers self- } \\
\text { control in indulgent, } \\
\text { unhealthful, or } \\
\text { unsustainable food } \\
\text { options? }\end{array}$ & $\begin{array}{l}\text { considering the } \\
\text { distribution of food } \\
\text { carefully? }\end{array}$ & $\begin{array}{l}\text { using noncoercive marketing } \\
\text { strategies and policies? }\end{array}$ & $\begin{array}{l}\text { nudging consumers to } \\
\text { eat and purchase more } \\
\text { healthful foods? }\end{array}$ \\
\hline
\end{tabular}


Table 4. Sample of the Novel Food Experience Design Future Research Arising from the Four FPs.

\begin{tabular}{|c|c|}
\hline FPs & Research Implications \\
\hline 运冚 & $\begin{array}{l}\text { - Who are the parties involved in and affected by the food experience? } \\
\text { - What are the vulnerable groups (e.g., children, consumers with eating disorders or low education levels) } \\
\text { within a given food experience? } \\
\text { - At which stage in the design of new foods and food experiences should the principle of nonmaleficence } \\
\text { be more relevant? } \\
\text { - How is the principle prioritized among conflicting interests of different stakeholders? }\end{array}$ \\
\hline 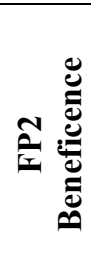 & $\begin{array}{l}\text { - Which factors contribute to beneficence in terms of the novel food experience design? } \\
\text { - How does the relationship between actors affect the novel food experience design given the impact of } \\
\text { strength on beneficence? } \\
\text { - Should the novel food experience design be expanded to include every possible stakeholder? } \\
\text { - Who is in charge of the required investments to generate higher levels of positive consequences for other } \\
\text { stakeholders? }\end{array}$ \\
\hline 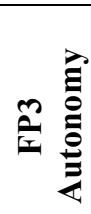 & $\begin{array}{l}\text { - What are the competency requirements to make an informed decision? } \\
\text { - How can consumers' sense of personal responsibility for the experience be enhanced? } \\
\text { - What are the marketing practices or heuristics that mislead decision-makers within an experience? } \\
\text { - Are specific groups (e.g., children, elderly, undereducated consumers) affected by marketing practices } \\
\text { differently than others? }\end{array}$ \\
\hline 志 & $\begin{array}{ll}- & \text { How can fairness be ensured? } \\
\text { - } & \text { How can fairness be measured? } \\
\text { - } & \text { How does fairness differ among various food experience contexts? } \\
\text { - } \quad \text { To what extent is fairness perceived subjectively? }\end{array}$ \\
\hline
\end{tabular}


Figure 1. Comparison of food design perspectives.

INNOVATION PROCESS APPROACH

Endemic

\section{DESIGN FOOD TO MAKE ME} RICH/HEALTHY

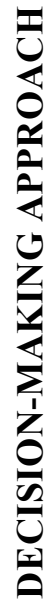

The economic approach

The ethical approach
Design of food products (vs. experiences) based on a restricted perspective that takes into account only the principal actor and disregards others' well-being

\section{DESIGN FOOD TO MAKE US} HAPPY

Design of food experiences based on assumptions and expectations about others' well-being pretending to know their point of view
Systemic

WE DESIGN FOOD TO MAKE US RICH/HEALTHY

Design of food experiences based on a restricted economic view of food wellbeing of every actor involved

WE DESIGN FOOD TO MAKE US HAPPY

Design of food experiences that generate food well-being for every actor involved 
Figure 2. The conceptual model of the novel food experience design.

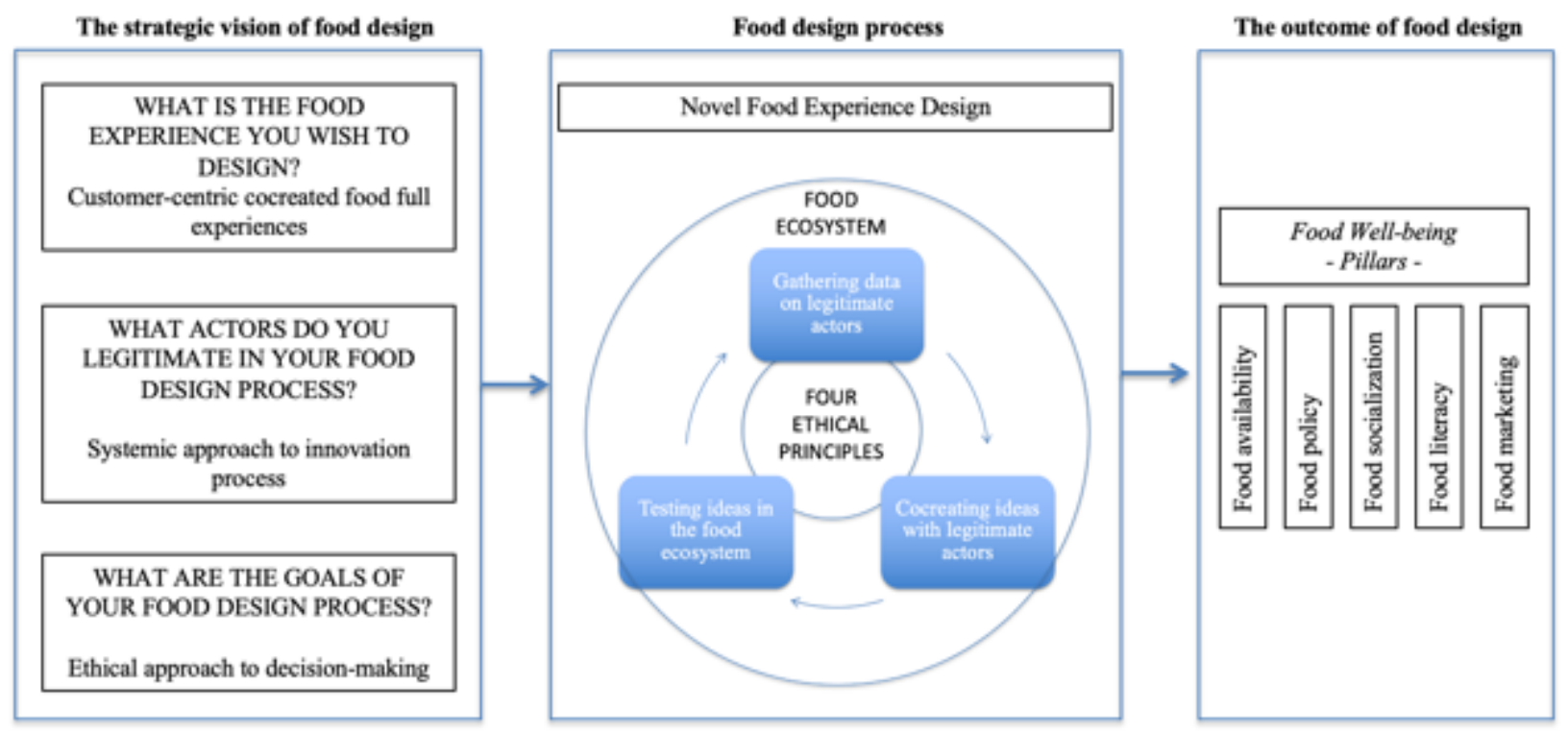


Figure 3. Managerial Self-Assessment Tool: How Consistent Is Your Strategic Vision with the Novel Food Experience Design?

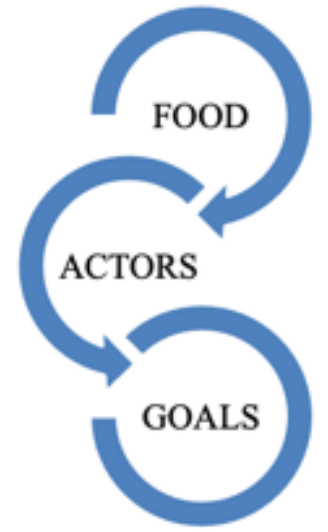

\begin{tabular}{|l|l|l|}
\hline $\begin{array}{l}\text { What is the food } \\
\text { experience you wish to } \\
\text { design? }\end{array}$ & $\begin{array}{l}\text { I design holistic, } \\
\text { connected food } \\
\text { experiences }\end{array}$ & $\begin{array}{l}\text { I focus on one single, } \\
\text { specific food activities at a } \\
\text { time }\end{array}$ \\
$\begin{array}{l}\text { What actors do you } \\
\text { legitimate in your food } \\
\text { design process? }\end{array}$ & $\begin{array}{l}\text { I take into account } \\
\text { every member of the } \\
\text { food ecosystem }\end{array}$ & $\begin{array}{l}\text { I take into account only } \\
\text { stakeholders with financial } \\
\text { power and influence }\end{array}$ \\
\hline $\begin{array}{l}\text { What are the goals of } \\
\text { your food design } \\
\text { process? }\end{array}$ & $\begin{array}{l}\text { I aim at generating food } \\
\text { well-being, assessed via } \\
\text { the sensorial, cognitive, } \\
\text { social, emotional, and } \\
\text { behavioral value } \\
\text { analysis }\end{array}$ & $\begin{array}{l}\text { I aim at generating } \\
\text { profitable food solutions, } \\
\text { assessed via the cost- } \\
\text { benefit analysis }\end{array}$ \\
& \multicolumn{2}{|c|}{$\begin{array}{c}\text { Resign } \\
\text { Novel Food Experience }\end{array}$} \\
\hline
\end{tabular}

Unintended consequences 
Figure 4. How to apply the novel food experience design.

1. Strategy. What you have to define

\begin{tabular}{|c|}
\hline 1.1. Food experience \\
\hline 1.2. Legitimate actors \\
\hline 1.3. Goals \\
\hline
\end{tabular}

4. KPIs. What you have to measure

\begin{tabular}{|c|c|c|c|c|}
\hline \multicolumn{5}{|c|}{ Food Well-being } \\
\hline 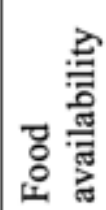 & 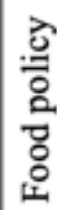 & ס & 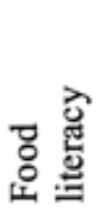 & 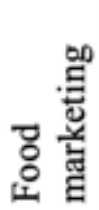 \\
\hline
\end{tabular}

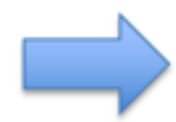

2. Innovation process. What you have to do

\begin{tabular}{|l|l|}
2.1 & $\begin{array}{l}\text { Gathering data on legitimate } \\
\text { actors }\end{array}$ \\
\hline $\begin{array}{l}\text { - Cocreating ideas with legitimate } \\
\text { actors }\end{array}$ \\
\hline
\end{tabular}

- Testing ideas in the food

2.3 ecosystem

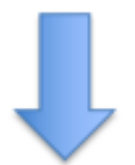

3. Decision-making. How you have to decide
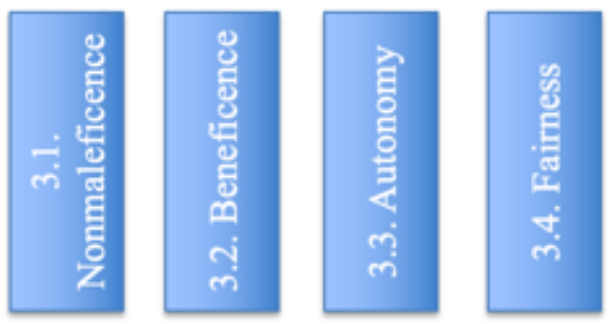